\title{
TREPANATION IN THE SARMATIANS OF THE LOWER VOLGA REGION (Revisiting its Causes and Origins)
}

Skull trepanation of the is one of the most frequently performed operations on human skull by modern and ancient surgeons. Trepanation is often associated in the scientific literature with such widespread manipulations in ancient peoples' bodies as deliberate head or extremities deformation, scalping, artificial scarification, decapitation and truncation of limbs, etc. Nowadays, it is known that trepanation is therapeutic or ritual manipulation done in vivo or posthumous. Also skull trepanation is performed by various techniques. The definition of all these criteria allows anthropologists to evaluate the nature of the development of medical knowledge of ancient societies, to determine the degree of technical sophistication of ancient doctors, to understand the traditions and customs of peoples who lived on earth in the distant past.

The paper is an attempt to summarize and consider cases of craniotomy on craniological materials dating back to the Sarmatian era. Evaluation of the described fixed manipulations from the point of view of the technique of carrying out the operations and the reasons for their conduct is also given in the study. An attempt was made to find the sources of the spread of the tradition of skull trepanation in the nomadic peoples of the Early Iron Age who inhabited the Lower Volga region.

Keywords: Trepanation, sarmatians, ancient societies, skull, Early Iron Age, the Lower Volga region.

Introduction. Paleoanthropological materials belonging to Sarmatian culture are a unique source of information that allows anthropologists and historians to learn about the way of life of the early nomads of the Lower Volga region. Thanks to the study of the Sarmatian bone remains, we were able to confirm ancient authors' data about the physical appearance of the population who had burial mounds in the South Russian steppes. The anthropologists have proved the existence of the Sarmatian tradition of deliberate artificial skull deforma- tion using scalping techniques widespread at a late stage of the Sarmatians history described by Herodotus and Ammianus Marcellinus. Paleoanthropological analysis of the nomads' remainings dating back to the early Iron Age also confirmed that the Sarmatians practiced military field medicine.

Currently, the main focus of archaeological and anthropological research is on the discovered skulls of the Sarmatian nomads with traces of trepanation originating from the territory of the Lower Volga region. Over the past 25 years, 3 brain capsules with perforations dating from the first centuries of our era.

Trepanation of the head is one of the oldest operations performed on the human skull (Brothwell 1972; Медникова 1997) which along with the deliberate and unintentional artificial deformation of the skull, limb amputation and scalping, was known in many ancient peoples of all the continents across the globe (Лисицын 2004; Фиалков 2010).

The very first mentions of trepanation are found in the works of ancient Greek healers Hippocrates and Galen. Hippocrates who lived between 460-370 BC gives evidence for trepanation in the division "On the wounds of the head» in chapter 9 . The ancient doctor described in details the causes and methods of conducting therapeutic operations on the head. Recommendations are given on monitoring the patient after the operation (Гиппократ 1936, с. 275-306).

Graeco-Roman physician Galen lived six centuries later than Hippocrates in 129-200 AD. In his scientific work "Head Damage» he also cites the methods of trepanation and suggests the reasons for this operation. In addition, the doctor gives descriptions of various instruments for trepanation: chisel, crown trephin, drill trefin, etc. (Mission 2007, p. 5-7). 
Trepanation of the skull was carried out for various purposes in the ancient peoples. As M. B. Mednikova indicates cause-effect fact underlies most classifications of trephine holes and the reasons for such manipulations. In general, at the moment, there are two main ways to classify trepanation (Медникова 1997).

1. Technique or method of performing operations on the skull (Wilson, Cantab 1923; Lisovski 1967; Brothwell 1972; Verano 2003; Erdal, Erdal 2011).

2. Classification of trepanation by purpose (Nemeskeri, Kinga-Kralovansky 1965; Brothwell 1972; Боев 1992; Aufderheide, Rodriguez-Martin 1998; Медникова 2001; 2004; Rubini 2008).

In Russia, scientific study of trepanation cases of the skull as a historical source of data telling us about the level of knowledge in such fields of science as traumatology and anatomy of the human body, the level of development of religious ideas, traditions and in general as a historical phenomenon began with the work of D. I. Anuchin who attempted to interpret the findings made by F. D. Nefedov in 1883 during excavations of the ancient settlement near the river Vetlugi namely pendants or amulet made from the human skull. D. N. Anuchin analyzes this subject in detail referring to similar findings and descriptions of trepanized skulls from the territory of Western Europe and South America. In the same work, the author considers incomplete trepanation on the skull of the Princes Mountain (hillfort in the Novgorod region), suggesting that in this case the operation was carried out using a tool similar to a chisel (Анучин 1895, с. 17).

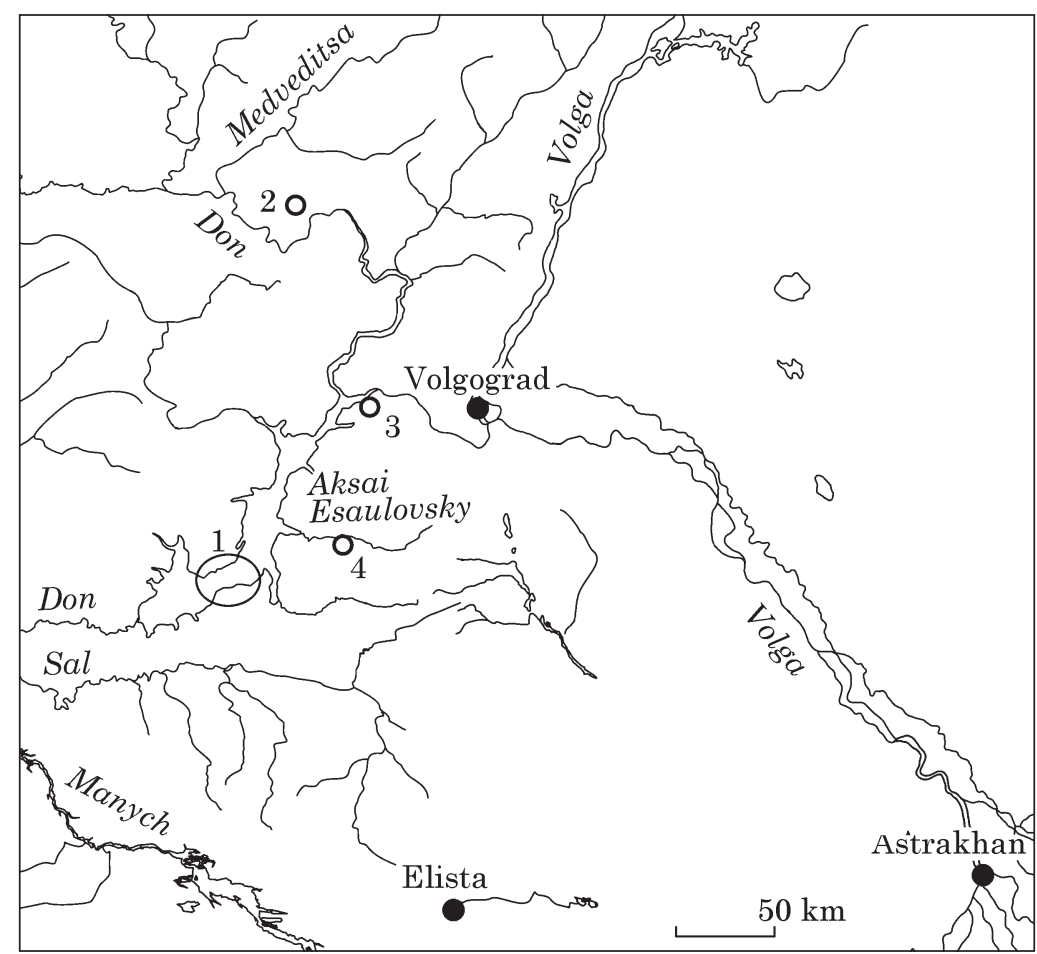

Fig. 1. Map-scheme of the Volgograd region and the location of trepanned skulls: 1 - the location of the burial grounds of the flood zone of the future Tsimlyansk reservoir; 2 - burial mound Glazunovsky; 3 - burial ground Peregruznoe I; 4 - burial ground Verbovsky I
The earliest cases of trepanation in the Lower Volga area are localized in the north of this territory in the Saratov region. So A. L. Nechitailo described the case of trepanation on the skull which was found by I. I. Dremov in 1985 on the Volga in the town of Engels in an eneolithic burial. The brain capsule belonged to a man. The operation was performed in vivo by scraping with a flint scraper (Нечитайло 2004, с. 61, 62).

Another ancient manipulation of a therapeutic nature, carried out on the cranium and dating to the Khvalynskiy culture was studied by A. A. Khokhlov. On the skull from the burial 21 of burial grounds Khvalynskiy II, the anthropologist revealed superficial trepanation at the wound site which testifies to the good medical skills of the ancient healers (Хохлов 2012, с. 121, 122).

In this paper the authors attempted to determine the causes and possible origins of the tradition of trepanation using the Sarmatian materials from the Lower Volga region.

Research Methods and materials. In the paper, 4 cases of trepanation in Sarmatians discovered on the materials from the territory of the Lower Volga region will be considered (fig. 1).

Case 1. The skull from the Don region (the modern territory of the Volgograd region, the Kalmyk republic and the Rostov region) presumably comes from the burial grounds of the flood zone of the future Tsimlyansk reservoir which were dug by detachments of the Volga-Don archaeological expedition under the guidance of M. I. Artamonov in 1949-1951 (Археологическая... 2009, c. 18). The radiography of the skull was published by D. G. Rokhlin in 1965 (fig. 2: 1). The bone remains originating from the burial date back to the early Sarmatian time of the 3rd-1st centuries BC.

Case 2. L. V. Gurenko conducted archaeological excavations in the Kumylzhensky district of the Volgograd region near the village Glazunovskaya in 1996. The mound of the Late Sarmatian burial of the $3^{\text {rd }}-4^{\text {th }}$ centuries was excavated. A skull with traces of trepanation and a lower jaw with holes were discovered in the burial (Гуренко 1997). The source of the case was an «Act of $F_{O}$ rensic Medical Exxamination No. 81 of 5-10 February 1998, prepared by forensic medical expert V. V. Sidorov. The medical expert conducted a macroscopic examination of a 30-year-old man's cranial capsule.

Case 3. Protective excavations of mounds near the village of Peregruznoye of the Oktyabrsky Area of the Volgograd Region were conducted in 2010. Bone remains of a 25-30 year-old woman with skull 
Fig. 2. Skulls of Sarmatian: 1 - X-ray of the skull of Sarmatian III-I cc. BC with a successful trepanation in the region of the cranial vault (Rokhlin 1965); 2 - trepanation hole on the skull of the Sarmatian middle III - beginning of the IV centuries AD from the burial mound Glazunovsky; 3 - trepanation of the skull of a Sarmatian woman from burial 3 of burial mound 45 of burial ground Peregruznoe I, I c. $\mathrm{AD} ; 4$ - trepanation of the skull of a woman from the burial I - first half of the II AD burial ground Verbovsky I
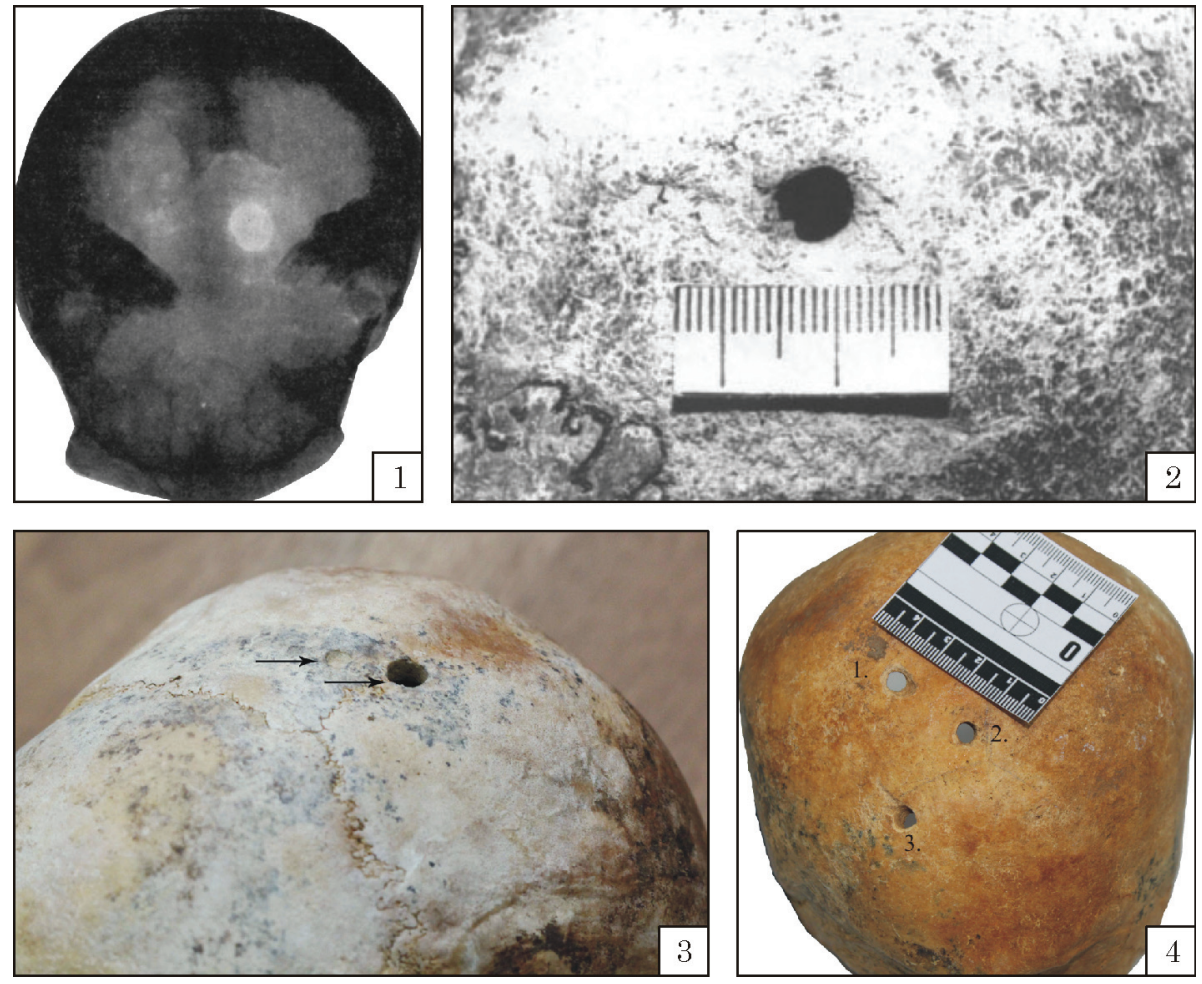

defects identifiable as trepanations were recovered during the archeological works in the burial mound 3 , mound 45 . The burial was attributed to the Middle Sarmatian culture and dates back to the $1^{\text {st }}$ century AD. The cranium of the woman was examined macroscopically. Radiographic study of the skull was carried out in 2 projections: left lateral and straightforward from the distance to the object of $1 \mathrm{~m}$. The radiation power is $70 \mathrm{~kW}$, $40 \mathrm{~mA}$ and the holding time is $0.16 \mathrm{sec}$. The X-ray device Medics-P-AMIKO was used to conduct radio graphical study (Перерва 2012, с. 123-133).

Case 4. During archaeological works in 2017 on the territory of the burial ground Verbovskiy I, a burial mound 26 with one burial dating back to the early $2^{\text {nd }}$ century $\mathrm{AD}$ was discovered. The burial contained a skull of a 35-45-year-old woman with three trepanation holes which was subject of examination.

For differential diagnosis the method of computed tomography was applied; the study was carried out on a 128-slice Computed Tomography Scanner "SOMATOM Definition» (Siemens) with two X-ray tubes, collimation slide $5 \mathrm{~mm}, 2 \mathrm{~mm}$ and $0.6 \mathrm{~mm}$ width and a $0.4 \mathrm{~mm}$ increment in the reconstruction of raw data. Multiplanar reformation in the sagittal and frontal projections and three-dimensional reformation using the three-dimensional visualization method were performed (Мамонтов и др. 2018, с. 88-90).

When describing the deformation performed on the skull from the burial ground Verbovsky, the recommendations set forth in the works of M. B. Mednikova were used (Медникова 1997; 2001). When determining post-mortem or in vivo nature of the revealed cranium deformations, the methods of forensic medical examination and mechanical in- juries traumatology on skeleton bones was used (Смолянинов 1959; Пиголкин и др. 2002).

Description of the Cases. As we have already mentioned above, there are relatively few cases of trepanation operations performed on the head dating from the Sarmatian time and originating from the territory of the Lower Volga region.

The Skull from the Don region. This is the case of the earliest trepanation of the Sarmatians of the 3rd-1st centuries BC. In the parietal bone there is a circular opening with smooth contours due to the presence of closed plates covering the spongy substance and connecting with the outer and inner plates of the parietal bone (fig. 2: 1). Traces of complications after the operative exchange of scientists have not been found. The operation most likely had a therapeutic nature (Рохлин 1965, с. 174, 195).

The Skull from the mound Glazunovsky. The study of the skull and its lower jaw was carried out by the forensic medical expert V. V. Sidorov who determined that in the posterior part of the parietal bone $32 \mathrm{~mm}$ on the right from the arrowshaped seam and $23 \mathrm{~mm}$ from the right branch of the lambdoid suture there is an oval-shaped trepanation hole with a tissue defect $7 \times 6 \mathrm{~mm}$ in size (fig. 2: 2). The edges of the damage are rounded out from the outside; the walls are chamfered in the direction from the rear in front, from right to left and downward. At six, four and eight o'clock positions, discoloration of the inner bone plate was detected with the formation of two notches and one protruding defect of the coal scallop.

During the study of the mandible at the base of both vertical branches V. V. Sidorov also discovered artificial holes. The analysis of manipulations on the 
skull allowed the expert to come to the conclusion that the lesions in the area of both vertical branches of the lower jaw were made in-vivo by drilling directed from the inside outwards and backwards, which could be performed as a ritual action. Trepanation in the posterior part of the parietal bone to the right was accomplished by the twisting action of a cylindrical-conical tool with three projecting ribs on the lateral surfaces, possibly an end part of the arrow with a metal tip (Сидоров 1996).

Skull from the burial Peregruznoye I. A circular defect of $5 \times 5 \mathrm{~mm}$ not having perforation in the cranial cavity was found when examining the cerebral capsule on the right parietal bone of the skull (fig. 2: 3). We observed a through $8 \mathrm{~mm}$ hole at $6 \mathrm{~mm}$ from the first lesion and $22 \mathrm{~mm}$ from the craniological point «bregma» touching the sagittal suture. The defect is round in shape. There are no traces of inflammatory process in the area of trepanation. The entrance edges of the hole are even sharp without traces of bone fracture. On the inner surface of the skull, the edges of the exit hole are also even without any traces of damage. Cracks have not been observed. The entrance and exit holes in the cranial cavity are of the same size, without traces of expansion. The walls of the hole are even. In the cut, the structure of the bone plate is clearly seen. Judging by the nature of the hole, the absence of chips, incisions, breaks, the operation was performed, most likely, using a drill with a semicircular tip as a tool by rotation (Перерва 2012, с. 128, 129).

Skull from burial ground Verbovsky $I$. On the border of the scales of the occipital bone and the left parietal bone, along the lambdoid suture, in the left parietal bone three trepanation holes are defined in the projection of the sagittal suture with clear and even contours (fig. 2: 4). The inner walls of the holes on sections are $0.6 \mathrm{~mm}$ thick and slightly serrated. The first full hole is located on the left parietal bone $20 \mathrm{~m}$ from the arrow-shaped suture and $26 \mathrm{~mm}$ from the anthropological landmark point Lambda. The second hole is located in the swept seam with a slight displacement to the left side $10 \mathrm{~mm}$ from the anthropological landmark Lambda. The third perforation is located in the occipital seam on the left side with a slight shift to the bottom.

The macroscopic description of the find and its investigation with the help of a computed tomography scan, as well as the archaeological context allows us to draw the following conclusions: the method of trepanation was drilling; the absence of traces of healing indicates premortal or posthumous nature of trepanation; the presence of a rich burial inventory in the pit from which the cranium was extracted, the multiplicity of holes and their localization may indicate the symbolic-ritual significance of the performed operation (Мамонтов и др. 2018, с. 88).

Discussion. From the above-described trepanation cases in Sarmatians, holes on the skull performed by drilling most likely posthumously or immediately before death with symbolic or ritual significance were discovered in three cases (burial grounds of Verbovsky, Peregruznoye and Glazunovsky).

Only trepanation, described by D. Rokhlin, originating from the excavations of M. Artamonov, being the earliest find, since it belongs to a representative of the Early Sarmatian culture, was most likely performed by technique of scraping. Judging by the fact that the traces of the inflammatory process in the field of surgery were not found by the researcher and there are signs of successful healing after manipulation, it can be assumed that the operation was of a therapeutic-surgical nature.

The earliest trepanation cases by the type of scraping in the Volga region were observed in the materials of the Bronze Age by I. Gohman (Гохман 1989, c. 7). The cases of trepanation recorded by $\mathrm{S}$. Rudenko on turtles of Central Kazakhstan from the Pazyryk and Shibinsk burial mounds of the Scythian time (Руденков 1960, с. 300-331), and by E. Murphy on the woman from the burial of the Scythian time of the burial cemetery Aymyrlig in Southern Siberia (VIII 21. Sk.3) are territorially and chronologically closer to our cases.

T. A. Chikisheva, A. V. Zubova et al. investigated trepanation on the anthropological materials of the early nomads from the burial grounds of Gorny Altai $4^{\text {th }}-3^{\text {rd }}$ centuries BC. According to the scientists, operations on the heads were performed for surgical purposes, and the method for carrying out trepanation was scraping (Чикешева и др. 2014, с. 130-141).

Thus, the findings of trepanized skulls from adjacent territories suggest that the emergence of skills for therapeutic trepanation in the Sarmatians of the Volga region could be a consequence of the transfer of eastern traditions. At the same time, one cannot deny that the manipulations might have been performed under the influence of ancient medicine achievements. However, in this case, the first option is more likely, since it more corresponds to the archaeological context of the origin of the Sarmatian antiquities in the territory of the South of Russia.

Now let us study the trepanation found on materials from the burial grounds of Glazunovsky, Peregruzhnoe I and Verbovskiy, which can be combined according to the technique of the operation performed which was drilling.

Drilling is one of the most common ways of carrying out trepanation in different peoples across the globe (Drennan 1937; Wilkinson 1975; Гохман 1989; Rawlings, Rossitch, 1994; Brothwell 1994; Campillo et al. 1999; Crubezya et al. 2001; Sankhyan, Weber 2001; Nystrom 2006; Бужилова, Добровольская, Медникова 2006; Acikkol et al. 2009; Likovsky, et al. 2010; Erdal, Erdal 2011; Pitsios, Zafiri 2012; Kurin 2013; Chorney et al. 2014; Бейсенов, Китов 2014; Tiago et al. 2015-2016).

Geographically and chronologically the closest materials are the finds of drilling trepanation of the skull found in Kazakhstan, Mongolia and Transcaucasia. 
Thus, P. Boev and O. Ismagulov described a trephined skull from the burial mound in the Karabye area of the Kounrad region of the Karaganda region of the Kazakh SSR. The skull box belonged to a man of 35-40 years. The burial was attributed to the 53 centuries BC. The scientists found 6 holes located obliquely from the upper medial to the lower medial side on the skull on the back of the left temporal bone and on the upper left side of the occipital. The diameter of the holes range from 7 to 7.5 (Боев, Исмагулов 1962, c. 131, 132). The possible cause of trepanation of the skull was a therapeutic operation probably because of the endocrine disease of the man, meanwhile the researchers admit the possibility of the patient's death during the operation or even post-mortem trepanation (Боев, Исмагулов 1962, с. 131, 132). M. B. Mednikova find the last option more likely to be the reason (Медникова, 1997, с. 139).

The group of researchers A. Z. Beisenov, A. O. Ismagulov, E. P. Kitov and A. O. Kitova, studying the population of Central Kazakhstan, referring to the Tasmolin culture $\left(8^{\text {th }}-5^{\text {th }}\right.$ centuries BC), described trepanation in 11 sculls. Ten of these 11 had through round holes made by drilling perforations. The operations were performed on nine male and one child's skull. In all cases, the defects are localized on the occipital bone or back of the parietal bones. The number of perforations on the skulls varies from 1 to 15. In addition to trepanation on some skulls, traces of scalping as well as special incisions crosswise were observed in the area of operations (Бейсенов и др. 2015 , с. $112-126)$. According to researchers, the cause of posthumous trepanation is most likely the need to preserve the body for longer period of time before the burial ceremony (Бейсенов и др. 2015 , c. 133). This conclusion was made by the scientists on the basis of the analysis of ethnographic data of the peoples of Kazakhstan and the spread of the mummification rite among the ancient peoples who inhabited this territory.

B. Naran and D. Tumen give a description of the skull 47-4 (AT-129) from the Chandman (Ulang) burial ground of the $7^{\text {th }}-3^{\text {rd }}$ centuries BC from the territory of Mongolia. Seven trepanation holes were found on the cerebral capsule. Several of them were drilled. Traces of healing were not revealed. Therefore, the researchers came to the conclusion that the patient died during the trepanation or the operation was performed after his death (Наран, Тумен 1997, с. 126, 127). B. Naran and $\mathrm{D}$. Tumen do not indicate the cause of trepanation in the man. Scientists only suggest that all 8 holes were made in stages, perhaps before death or posthumously (Наран, Тумен 1997, с. 127).

A. Khudaverdian described trepanation performed by drilling on the skull of a young woman from the pit of the 1st burial ground of Karamir $\left(9^{\text {th }}-8^{\text {th }}\right.$ centuries BC) from the territory of Armenia. A through hole measuring $14 \times 12.5 \mathrm{~mm}$ was revealed in the sagittal seam. The edges of the lesion testify to the premarital or postmortem character of trepanation (Худавердян 2015, с. 122).
An overview of the trepanation findings carried out by a drill from adjacent territories indicates the eastern roots of this custom. The cult traditions of manipulating the human skull, along with the presence of eastern innovations in the material culture of the Sarmatians of this time, probably originated in the vast territory from Central to Middle Asia.

Considering the reasons for the skull holes appearance in the Middle Sarmatian women from the burial grounds of Verbovsky I and Peregruzhnoe, as well as in the man from the late Sarmatian burial of the Glazunovsky burial ground, one should start from interpretations and explanations of the cases of trepanation that were revealed on the anthropological materials of the early Iron Age.

So, referring to the work of Hungarian scientists D. A. Kirichenko reviewed the findings of trepanized skulls of the Sarmatian time from the territory of Hungary. He found three surgical operations that were performed in vivo and had a favorable outcome on Hungarian materials. And there was another case of a postmortem operation on the skull found in the burial 52 of the Csengele cemetery which was of a ritual symbolic nature. The operations on all skulls from Hungary were performed by scraping and cutting (Кириченко 2007, с. 63-66).

S. I. Rudenko found mummified corpses with trepanation of the skull in the Pazyryk Barrow II dating back to the Scythian era ( $5^{\text {th }}$ century BC). Similar findings were made by S. I. Rudenko in the Shibinsky mound of the $2^{\text {nd }}-1^{\text {st }}$ centuries BC. (Руденко 1953, с. 342-360). S. I. Rudenko explains the causes of skulls trepanation from this burial mound by the funeral rite traditions of Pazyryk (Руденко 1949, с. 97-109).

Later S. I. Rudenko expressed another idea on the causes of skull trepanation from the Pazyryk barrows. He links this manipulation to the extraction of the brain, which was necessary for the mummification of the corpse (Руденко 1953, с. 104-145).

S. V. Kiselev described the features of the archaeological antiquities of the Tashtyk era on the Yenisei and recorded cases of post-mortem trepanation of the skull in the occipital area. The scientist like I. S. Rudenko suggested that the operations were carried out to extract the brain and prepare the corpses for mummification. S. V. Kiselev thought that trepanation and mummification in the era of Tashtyk burials $\left(2^{\text {nd }}\right.$ century $\mathrm{BC}-$ $5^{\text {th }}$ century $\mathrm{AD}$ ) was a fairly common custom in the peoples of the East (Киселев 1951, с. 403).

Cases of posthumous trepanation found on the materials of Tashtyk culture, were also studied by I. I. Gohman. In some repositories, according to the researcher, the frequency of trephined skulls reaches $80-90 \%$. Trepanation is localized in the occipital part. The types of trepanation in each cemetery vary which indicates the spread of specific traditions (Гохман 1989, с. 5-10).

L. V. Kyzlasov explained the posthumous trepanation on the skulls of the Tashtyk culture 
by the fact that the corpse before the burial apparently was turned into a skeleton "for what was the posthumous trepanation of the skull...» (Кызласов 1960). This point of view was reasonably criticized by A. N. Lipsky, who studied in detail the ethnography of funeral rites of northwestern Mongols, Altaians, Khakas, Tungus, Gold-Nanai and other Siberian nationalities. No traces of this kind of customs in the above-mentioned peoples were found. The researcher suggests that trepanation should be associated with a religious or therapeutic purpose which was intended to «release», "expel» the spirit that caused pain in the skull (Липский 1966, с. 107).

M. B. Mednikova investigated series of the Late Tengar period from the burials Samokhval, Tagarsky Island and Kazyl-Kul. The researcher described post-mortem trepanations differing greatly in form performed in numerous anthropological materials using various methods. The reason for the implementation of these manipulations with the skull box by representatives of the Tagar culture is associated with ritual actions (Медникова 1997, с. 138).

A. D. Grach revealed trepanation on the anthropological materials of the Saglyn culture from the burial grounds of Sagly-Bazhi II and MazhalykKhovuzu I, II, from the territory of the Republic of Tuva. Trepanation holes were made in the frontal, occipital, parietal bones of skulls. The researcher suggested that perforations were made to extract the brain. The author indicates that such operations were usually used in the embalming of corpses, which was widespread in various areas of the ancient world: in Assyria, Media, in the Persians and the Egyptians. In addition, the author points out that the embalming of corpses of deceased noblemen was in the custom of various tribes of the «Scythian» world (Грач 1980).

We should also pay attention to the work of E. Murphy, who investigated the anthropological materials of the Aymyrlig cemetery from the Ulus-Khem area of Tuva. She studied the skull of a woman with a hole in the left part of the frontal bone which was performed for therapeutic purposes and perforation on the skull of a teenager performed posthumously as part of a ritual or for trophic purposes (Murphy 2003, p. 211-220).

An analogical case of perforations on the lower jaw found in an individual from the Glazunovsky burial ground is described in the work of E. P. Kitov who studied skulls from the Berel burial ground dating back to the Pazyryk culture of the $4^{\text {th }}-3^{\text {rd }}$ centuries BC. The researcher found through holes drilled posthumously on both branches of the lower jaw of a 45-55-year-old man from the mound 16. E. P. Kitov suggested that perforations on the lower jaw were probably made to fix the jaw in its natural state after the removal of the muscles, and the arrangement of the holes indicates its fixation to the cheekbone $\operatorname{arch}$ (Бейсенов, Китов 2014, с. 34-40).
So most of the researchers (I. S. Rudenko, A. D. Grach， S. V. Kiselev， L. V. Kyzlasov, etc.), referring to the wide dissemination among the peoples of Central Asia of the ritual of mummification of corpses and the presence of traces of trepanation on their skulls, as well as the ethnographic parallels of the Kazakh people, put forward the hypothesis that trepanation is a preliminary or preparatory procedure for the mummification of the corpse or its embalming. In this way, the ancient operators released the skull of the deceased person from biomass, which undergoes rapid decomposition, making the cerebral capsule hollow or filling it with a preservative, for better preservation of external soft tissues. This point of view is likely to have a right to exist, especially with regard to the cultures of Central and Middle Asia. In cases with anthropological materials from the territory of the Lower Volga region, such a explanation of skull trepanation is unlikely since the tradition of mummification and embalming with respect to peoples from this territory is not confirmed in written sources and by archaeological works.

At the same time, an overview of the findings of posthumous trepanation, as well as an interpretation of their purpose, makes it possible to suggest that trepanation on sarmatian skull from the burial ground Verbovsky I, Peregruznoe I and Glazunovski is of a ritual character, and the appearance of postmortem drill trepanation in the Sarmatians of the middle and late stages is most likely proof of the common cultural and religious development of the Sarmatian world and cultures of Central and Middle Asia, which on the whole is confirmed by archaeological material.

At the same time, an overview of the drilling trepanation case, as well as interpretation of their purposes make it possible to suggest that trepanation on the skulls in the Sarmatians from the burial grounds of Verbovsky I, Perevruznoye and Glazynovsky could have a ritual character. The appearance of drilling trepanation in the Sarmatians of the middle and late stages is most likely a proof of the common cultural and religious development of the Sarmatian world and cultures of Central and Middle Asia in the first centuries of our era, which has mostly been confirmed by archaeological material.

So back in 1992, A. S. Skripkin proposed a hypothesis on the significant influence of the cultural traditions of the population of Central and Middle Asia on the Sarmatian world of the VolgaDon region which can be explained by a series of migrations from these eastern regions in the last centuries $\mathrm{BC}$ and the first centuries AD.

As a result of an important nomadic unification was led by the Hun who practiced aggressive policies towards the neighbors. This event led to cultural transformations in such territories as Southern Siberia, Kazakhstan and Central Asia. Old Scythian traditions are replaced by new stereotypes. Subsequently, strengthening of new innovative processes was observed on the territory 
of the Lower Volga region in the $1^{\text {st }}$ century AD. Since that time, Chinese and «Bactrian» type mirrors have spread in the Sarmatian burials; small cast bronze cauldrons with plums and handles in the form of animal figures, for a number of details of the nearby Saka cult dishes; bracelets with conical thickenings at the ends, having a wide range of analogies in Central Asian antiquities; some types of weapons (ceremonial daggers in a sheath with lobes for fastening, bows with bony pads, arrowheads and swords with a ring-shaped top; Скрипкин 1992, с. 19, 20). Since that time, Tamgas are widely spread in the Volga region, the Don and the Northern Black Sea coast, identical to Central Asian and Mongolian antiquities.

All these changes in cultural traditions are associated with the appearance of the Alans in the Lower Volga and in the Black Sea steppes. According to A. S. Skripkin, the foundation of the Alanian ethnos is formed in Central Asia on the basis of the nomadic peoples of the eastern Scythians and others (Скрипкин 1992, с. 39, 40).

A similar theory was developed by S. A. Yatsenko who pointed out that the formation of social and cultural stereotypes of the population of the Lower Volga, the Lower Don and the Northern Black Sea regions was influenced by the genetic connections of the ancestors of the Alans with the South-Kazakhstan "nomadic empire» of the Kangyu / Kangha era of its heyday (Яценко 2006, с. 123-125).

In this regard, the burial with trepanation from the Glazunovsky burial ground, which was performed in the so-called T-shaped catacomb is worth considering. According to V. Yu. Malashev (2009) and M. V. Krivosheev (2017), the use of this kind of grave constructions might have been associated with the traditions that are typical for the Alanian and Early Alan culture of the Central Caucasus (Малашев 2009, с. 49; Кривошеев 2017, c. 17-27).

In this regard, the answer to the question of origins and parallels of trepanation in the Sarmatians of the middle and late stages is obvious. Probably, along with funeral traditions and innovations in material culture which are observed in archaeological complexes of the $1^{\text {st }}-2^{\text {nd }}$ centuries $\mathrm{AD}$ and $2^{\text {nd }}-4^{\text {th }}$ centuries $\mathrm{AD}$, migrants from the east brought customs associated with manipulation of the head, for example, trepanation and skull deliberate artificial deformation occurs in $70 \%$ of cases in the late Sarmatians.

Let us dwell on several circumstances related to the archaeological context of burial from the ground Verbovsky and Peregruznoye, on what kind of information they can provide to understand the reason for the appearance of holes on the skulls.

1 . Burial 1 from the mound 26 of the burial ground Verbovsky I has a high degree of similarity with burial 3 from the mound 45 of the burial ground Peregruznoye I. Firstly, in the chronological perspective, both graves were made in the $1^{\text {st }}-2^{\text {nd }}$ centuries $A D$ Secondly, a set of funeral inventory objects is simi- lar in many respects. So in both burials there were fragments of large ceramic vessels made on a potter's wheel, fragments of stucco, various small syringes such as censers and balsamaria, bronze mirrors, iron implements (shiltsa, needles), bone spoons, a large and diverse set of beads and amulets, practically identical sets of gold plaques (Kurgan... 2014, p. 66, 67). Thirdly, the same construction of the grave is observed, the pit is rectangular.

2 . According to the authors of the excavations of Verbovsky I and the Peregruznoye I, the women buried there probably belonged to the wealthy strata of the Sarmatian population, since the accompanying inventory of these graves is very expressive. In this regard, it is interesting that censers, bone spoons, a set of individual objects (shells, pendants from fragments of ceramics, chalk and bronze) were found in the burials which could well be amulets, amulets, allow us to talk about the possible fulfillment by the woman of priestly duties (Яценко 2007, с. 4). In this regard, it will be appropriate to recall the assumption that was made by I. S. Rudenko that the trepanation of the skull in the Pazyryk barrows was practiced exclusively with regard to influential persons, since no trepanations were found on skulls from the mediocre burials (Руденко 1949, с. 97-109). A. Z. Beisenov and E. P. Whales also indicate high social status of individuals with postmortem drilling trepanation of the skull, calling the burials of these people the elite of the Tasmolinsk archaeological culture. This conclusion is drawn on the basis of the large size and complexity of the constructions of the sepulchral structures, as well as the presence in the burials of the prestigious inventory of the Early Saka period (Бейсенов, Китов 2014, с. 31).

3. A ritual of rendering harmless or as it is also called a ritual looting of the grave was conducted in both burial places. The rituals were characterized by a partial (burial of Peregruznoye) or complete (burial of Verbovsky) destruction of the integrity of the deceased.

The latter circumstance deserves special attention. Rites of ritual robbery and neutralization of the deceased are quite widespread in ancient peoples of Eurasia. A rather extensive literature is devoted to the problem of interpretation of such ritual practices, among which the works of such scientists as S. A. Tokarev (1990), Yu. A. Smirnov (1997), V. S. Flerov (2000), O. V. Zaitseva (2005) should be recalled.

Descriptions of the ritual of rendering harmless and ritual plundering in Scythian-Sarmatian burials and their interpretation are available in the works of S. A. Abramova (1968), V. S. Flerov (2000), M. A. Grigorieva, S. G. Leonova (2015), N. A. Gavrilyuk, N. P. Timchenko (2016), S. A. Yatsenko (2016), E. V. Vdovichenkov, S. M. Ilyashenko (2016).

And if we take into account that in relation to individuals from the burial grounds of Perevruzhnoye I and Verbovsky I, manipulations were carried 
out as a rite of rendering the deceased in the form of plundering the burial and violating the integrity of the skeleton, it can be assumed that it was within the framework of these ritual actions in the burials of the middle Sarmatian time that trepanation on the skulls of women could have been performed.

The symbolic meaning of trepanation of the skull in this case becomes part of the funeral rite or special ritual aimed at providing protection from a deceased person who could harm relatives or members of society.

Conclusions. 1. The origins of the trepanation tradition in the Sarmatians from the territory of the Lower Volga region should be traced from the ancient peoples who lived there in $8^{\text {th }}$ $1^{\text {st }}$ centuries BC in Central and Middle Asia. Most likely, ethnological and political processes that took place in this territory led to the emergence of new cultural traditions (including posthumous trepanation) in the first centuries of our era on the territory of the South Russian steppes.

2 . The Sarmatian remains originating from the Lower Volga region often carry traces of trepanation made by drilling techniques, performed with a tool less than $6-8 \mathrm{~mm}$ in diameter. Analogies are found in the monuments of Western, Central and Eastern Kazakhstan of $5^{\text {th }}-3^{\text {rd }}$ centuries BC according to drilling type of trepanation performed.

3 . There is no doubt about ritual and symbolic significance of the manipulations performed on the Sarmatian skulls from the burial grounds of Verbovsky, Perevruznoye and Glazunovsky. At the same time, an open question remains whether within the framework of what ritual or tradition these artificial manipulations with the human skull were carried out: a preparatory procedure for the mummification of the corpse or its embalming; preparation of the corpse for burial or long-term storage; the deliverance of the corpse, «liberation» or "expulsion» of the enshrouded spirit that caused pain; ritual looting and sabotage with the goal of «locking» the unwanted dead.

4. The Sarmatians of the Lower Volga region could have performed operations on the skull not only for ritual or symbolic purposes. The nomads of the south of Russia in the era of the early Iron Age knew and were able to do therapeutic trepanation, which as in the case of posthumous perforations, most likely originates from the territory of Siberia and Kazakhstan.

5 . The problem of interpreting of perforations on the lower jaw of the man from the burial of Glazunovsky remains unresolved. Traces of healing, revealed in the field of operation, do not allow us to correlate this case with the perforations described by E. P. Kitov on the skull of the Pazyryk culture from the burial ground Berel from Easten Kazakhstan.

Note. This work was supported by grant No. 19-09-00471 of the Russian Foundation for Basic Research (RFBR) «Paleoanthropology of the ancient and medieval population of the Lower Volga River region (paleopathological aspect)».

\section{BIBLIOGRAPHY}

Acikkol, A., Gunay, i., Akpolat. E., Gulec, E. 2009. A middle bronze age case of trephination from central Anatolia, Turkey. Bulletin International Association Paleodontology, 3, 2, p. 28-39.

Brothwell, D.R. 1994. Ancient Trephining: Multi-focal evolution or Trans-World Diffusion? Journal of Paleopathology, 6, 3, p. 129-139.

Brothwell. D.R. 1972. Digging up Bones. London: Trustees of British Museum.

Campillo. D., Safont, S., Malagosa, A., Puchalt, F.-J. 1999. Four trepanned skull from $5^{\text {th }}$ and $16^{\text {th }}$ century in Spain. Surgery or ritual? Cronos, 2, 2, p. 261-283.

Chorney, M. A., Gandhi, Ch. D., M. D., Prestigiacomo, Ch. J. 2014. Berengario's drill: origin and inspiration. Neurosurgery Focus, 36, 4, p. 1-7.

Crubezy, E., Bruzek, J., Guilaine, J., Cunha, E., Rouge, D., Jelinek, J. 2001. The antiquity of cranial surgery in Europe and in the Mediterranean basin. Earth and Planetary Sciences, 332, p. 417-423.

Drennan, M. R. 1937. Some Evidence for a Trepanation Cult in the Bushman Race. Medical Journal, Maart 27, p. 3-6.

Erdal, Y. S., Erdal, O. D. 2011. A Review of Trepanations in Anatolia with New Cases. International Journal of Osteoarchaeology, 21, p. 505-534.

Kurin, D. S. 2013. Trepanation in South-Central Peru During the Early Late Intermediate Period (ca. AD 1000-1250). American Journal of Physical Anthropology, 152, p. 484-494.

Likovsky, Ja., Malykova, Dr., Brzobohata, H., Stranska, P. 2010. Causation and methods of skull trepanation in the past from the point of view of the latest findings from the Czech territory. Anthropologie, XLVIII, 1, p. 19-32.

Missios Symeon, M. D. 2007. Hippocrates, Galen, and the uses of trepanation in the classical world. Neurosurg. Focus, 23, p. 1-9.

Murphy, E. M. 2003. Trepanations and Perforated Crania from Iron Age South Siberia: An Exercise in Differential Diagnosis. In: Arnott, R., Finger, S., Smith, C. U. M. (eds.). Trepanation: History, discovery, theory. Lisse: Swets \& Zeitlinger Publishers, p. 209-221.

Nemeskeri, J., Kralovansky, A., Harsanyi, L. 1965. Trephined skulls from the tenth century. Acta Archaeologica Academiae Scientiarum Hungaricae, XVII, p. 343-367.

Nystrom, K. C. 2007. Trepanation in the Chachapoya region of Northern Peru. International Journal of Osteoarchaeology, 17, 1, p. 39-51.

Pitsios, Th., Zafiri, V. 2012. Cases of Trephination in Ancient Greek Skulls. International Journal of Caring Sciences, 5, 3, p. 239-245.

Rawlings, Ch. R., Rossitch, E. 1994. The History of Trephination in Africa with a Discussion of Its Current Status and Continuing Practice. Surgical Neurology, 41, p. 507-513.

Rubini, M. 2008. A Case of Cranial Trepanation in a Roman Necropolis (Cassino, Italy, $3^{\text {rd }}$ Century BC). International Journal of Osteoarchaeology, 18, p. 95-99.

Sankhyan, A. R., Weber, G. H. J. 2001. Evidence of Surgery in Ancient India: Trepanation at Burzahom (Kashmir) over 4000 Years Ago. International Journal of Osteoarchaeology, 11, p. 375-380.

The Cambridge... 1998. The Cambridge Encyclopedia of Human Paleopathology by Arthur C. Aufderheide \& Conrado Rodriguez-Martin. Cambridge: Cambridge University.

Tiago, T., Ana Maria, S., Collado, G. H., Oosterbeek, L. 2015-2016. Prehistoric trepanation in the Iberian Peninsula: a new case from the province of Badajoz (Extremadura, Spain). Antropologia Portuguesa, 32-33, p. 47-60.

Verano, J. W. 2003. Trepanation in Prehistoric Souht America: Geographic and Temporal Trends over 2,000 Years. In: Trepanation. History, Discovery, Theory. Lisse; Abingdon; Exton; Tokio: Swets \& Zeitlinger, p. 223-236.

Wikinson, R. G. 1975. Trephination by drilling in ancient Mexico. Bulletin of the New York Academy of Medicine, 51, 7, p. 838-850. 
Wilson Parry, T., Cantab, M. D. 1968. Trephination of the living human skull in prehistoric times. The British Medical Journal, 1923, p. 457-461.

Абрамова, С. А. 1968. Новые погребения сарматского времени из Кабардино-Балкарии. Советская археология, 3, с. 114-130.

Анучин, Д. Н. 1895. Амулет из человеческого черепа и трепанация черепов в древности, в России. Tруды XIV археологического съезда, 1, 4, с. 18.

Балабанова, М. А., Перерва, Е. В. Клепиков, В. М., Кривошеев, М. В., Демкин, В.А., Ельцов, М. В., Скрипкин, А. С., Удальцов, С. Н., Яворская, Л. В., Дьяченко, А. Н. 2014. Курганный могильник Перегрузное I: результаты междисииплинарных исследований. Волгоград. ФГБОУ ВПО РАНХиГС.

Бейсенов, А. З., Исмагулова, А. О., Китов, Е. П., Китова, А. О. 2015. Население Центрального Казахстана в I тысячелетии до н. ә. Алматы: Институт археологии им. А. Х. Маргулана.

Бейсенов, А. З., Китов, Е. П. 2014. Посмертная трепанация черепов в элитных захоронениях сакской эпохи Центрального Казахстана. Известия АлтГУ, 4-2, 84, с. 31-41.

Боев, П., Исмагулов, О. 1962. Трепанированный череп из Казахской ССР. Советская этнографбия, 2, с. 131-132.

Бужилова, А. П., Добровольская, М. В., Медникова, М. Б. 2006. К проблеме реконструкции социальных взаимоотношений населения Барабинской степи (анализ травм и повреждений по антропологическим материалам серии Сопка 2). Археология, этнограббия и антропология Евразии, с. 148-156.

Вдовченков, Е. В., Ильяшенко, С. М. 2016. Древние ограбления некрополя Танаиса (к постановке проблемы). Труды ИИМК РАН, 46: Древние некрополи и поселения: постпогребальные ритуалы, символические захоронения и ограбления, с. 157-168.

Гаврилюк, Н. А., Тимченко, Н. П. 2016. Феномен ограбления степных скифских погребений в «макроэкономике» Северного Причерноморья. Труды ИИМК РАН, 46: Древние некрополи и поселения: постпогребальные ритуалы, символические захоронения и ограбления, с. 129-133.

Гиппократ, 1936. Избраннье книги. Москва: Гос. изд-во биол. и мед. лит.

Гохман, И. И. 1980. Палеоантропология и доисторическая медицина. В: Алексеева, Т. И. (ред.). Антропология медицине. Москва: МГУ, с. 5-16.

Грач, А. Д. 1980. Древние кочевники в иентре Азии. Москва: Наука

Григорьева, М. А., Леонова, С. Г. 2015. «Страх и трепет»: обряд обезвреживания в погребальной практике ираноязычных кочевников Северного Кавказа. Кант. 3,16 , с. $16-21$

Гуренко, Л. В. 1997. Отчет о проведении археологи ческих исследований в Кулылженскол районе Волгоградской области (у станицы Глазуновской) в 1996 г.

Зайцева, О. В. 2005. Погребения с нарушенной анатолической иелостностью костяка: методика исследования и возможности интерпретации: Дисертащия к. и. н. Томск.

Кириченко, Д. А. 2007. О трепанации черепа в древности. Azsrbaycan arxeologiyasэ vəetnoqrafiyasə, 1, с. 63-67.

Киселев, С. В. 1951. Древняя история Южной Сибири. Москва: Наука.

Кривошеев, М. В. 2017. Восточные традиции и инновации в сарматских памятниках второй половинь II-IV в. н. э. Вестник Волгоградского государственного университета. Серия 4: История. Регионоведение. Международные отношения, 22, 4, с. 17-27.

Кызласов, Л. Р. 1960. Таштыкская эпоха в истории Хакасско-Минусинской котловиньь (I в. до н. э. - Vв. н. э.). Москва: МГУ.

Липский, А. Н. 1966. К вопросу об использовании этнографии для интерпретации археологических материалов. Советская этнографбия, 1, с. 105-118.

Лисицын, Ю. П. 2004. История медииины. Учебник. Москва: Гэотар.
Малашев, В. Ю. 2009. Позднесарматская культура: верхняя хронологическая граница. Российская археология, 1, с. 47-51.

Мамонтов, В. И., Обраменко, И. Е., Перерва, Е. В. 2018. Трепанация черепа из захоронения среднесарматского времени с территории Волгоградской области. Вестник Московского университета. Серия 23: Антропология, 1 , с. 86-100.

Медникова, М. Б. 1997. К вопросу о распространении посмертной трепанации черепов в Центральной Азии. Российская археология, 4, с. 130-188.

Медникова, М. Б. 2001. Трепанации у древних народов Евразии. Москва: Научный мир.

Медникова, М. Б. 2004. Трепанации в древнем мире и культ головы. Москва: Алетейа.

Наран, Б., Тумен, Д. 1997. Травматические повреждения на черепах Чандманьского могильника. Российская археология, 4, с. 122-130.

Нечитайло, А. Л. 2004. Энеолитические погребения с перфорированными черепами в степях Евразии. В: Проблемы археологии Нижнего Поволжья. I Международная Нижневолжская археологическая конферениия. Тезисы докладов. Волгоград, с. 61-63.

Перерва, Е. В. 2012. Случай трепанации у сарматов (по антропологическим материалам из могильника Перегрузное I). Вестник Московского университета. Cерия XXIII, 2, с. $123-133$.

Пиголкин, Ю. И., Баринов, Е. Х., Богомолов, Д. В., Богомолова, И. Н. 2002. Судебная медицина. Москва: Гәотар-мед.

Рохлин, Д. Г. 1960. Болезни древних людей (кости людей различных эпох нормальные и патологические изменения). Москва; Ленинград: Наука.

Руденко, С. И. 1949. Культура Алтая времени сооружения пазырыкских курганов. Краткие сообщения ИИМК, XXVI, с. 97-109.

Руденко, С. И. 1953. Культура населения Горного Алтая в скифбское время. Москва; Ленинград: АН СССР.

Руденко, С. И. 1960. Культура населения Центрального Алтая в скифбское время. Москва; Ленинград: $\mathrm{AH}$ CCCP.

Сидоров, В. В. 1997. Акт судебно-медицинского исследования № 8. В: Гуренко, Л. В. Отчет о проведении археологических исследований в Кульлюеенском районе Волгоградской области (у станицы Глазуновской) в 1996 г. Архив № 8.

Скрипкин, А. С. 1992. Азиатская Сарлатия. Проблемы хронологии, периодизации и этнополитической истории. Научный доклад, представленный в качестве диссертации на соискание ученой степени доктора исторических наук. Москва.

Скрипкин, А. С. (ред.). 2009. Археологическая энииклопедия Волгоградской области. Волгоград: ВолГУ.

Смирнов, Ю. А. 1997. Лабиринт: мифбология преднамеренного погребения. Москва: Восточная литература.

Смольянинов, В. М. 1959. Судебная медииина: учебник для студентов мед. ин-тов. Москва: Медгиз.

Токарев, С. А. 1990. Ранние фборль религии. Москва: Политиздат.

Фиалков, Л. 2010. История медииины. Хайфра: JKDesign.

Флеров, В. С. 2000. Аланьц Центрального Предкавказья V-VIII веков: обряд обезвреживания погребенных. Труды Клин-Ярской экспедиции, I. Москва: Полимедиа.

Хохлов, А. А. 2012. Ритуальные травмы на черепах у носителей хвалынской энеолитической культуры Поволжья. Этнограббческое обозрение, 2, с. 118-125.

Худавердян, А. Ю. 2015. Трепанированные черепа из погребений эпохи поздней бронзы и раннего железного века с территории Армении. Вестник археологии, антропологии и этнографби , 2, 29, с. 115-127.

Чикишева, Т. А., Зубова, А. В., Кривошапкин, А. Л., Курбатов, В. П., Волков, П. В., Титов, А. Т. 2014. Комплексное исследование трепанаций у ранних кочевни- 
ков Горного Алтая. Археология, этнографбя и антропология Евразии, 1, 57, с. 130-141.

Яценко, С. А. Костюм древней Евразии (ираноязычньєе народы). Москва: Восточная литература.

Яценко, С. А. 2007. О женщинах-«жрицах» у ранних кочевников (на примере знатных сарматок I в. до н. э. II вв. н. э.). Мировоззрение народов Южной Сибири и Центральной Азии в исторической ретроспективе, 1, с. 1-8.

Яценко, С. А. 2016. Характер древних ограблений курганов двух групп сарматской элиты I-II вв. н. э. Труды ИИМК РАН, 46: Древние некрополи и поселения: постпогребальные ритуалы, символические захоронения и ограбления, с. 147-156.

\section{REFERENCES}

Acikkol, A., Gunay, i., Akpolat. E., Gulec, E. 2009. A middle bronze age case of trephination from central Anatolia, Turkey. Bulletin International Association Paleodontology, 3, 2, p. 28-39.

Brothwell, D.R. 1994. Ancient Trephining: Multi-focal evolution or Trans-World Diffusion? Journal of Paleopathology, 6, 3, p. 129-139.

Brothwell. D.R. 1972. Digging up Bones. London: Trustees of British Museum.

Campillo. D., Safont, S., Malagosa, A., Puchalt, F.-J. 1999. Four trepanned skull from $5^{\text {th }}$ and $16^{\text {th }}$ century in Spain. Surgery or ritual? Cronos, 2, 2, p. 261-283.

Chorney, M. A., Gandhi, Ch. D., M. D., Prestigiacomo, Ch. J. 2014. Berengario's drill: origin and inspiration. Neurosurgery Focus, 36, 4, p. 1-7.

Crubezy, E., Bruzek, J., Guilaine, J., Cunha, E., Rouge, D., Jelinek, J. 2001. The antiquity of cranial surgery in Europe and in the Mediterranean basin. Earth and Planetary Sciences, 332, p. 417-423.

Drennan, M. R. 1937. Some Evidence for a Trepanation Cult in the Bushman Race. Medical Journal, Maart 27, p. 3-6.

Erdal, Y. S., Erdal, O. D. 2011. A Review of Trepanations in Anatolia with New Cases. International Journal of Osteoarchaeology, 21, p. 505-534.

Kurin, D. S. 2013. Trepanation in South-Central Peru During the Early Late Intermediate Period (ca. AD 1000-1250). American Journal of Physical Anthropology, 152, p. 484-494.

Likovsky, Ja., Malykova, Dr., Brzobohata, H., Stranska, P. 2010. Causation and methods of skull trepanation in the past from the point of view of the latest findings from the Czech territory. Anthropologie, XLVIII, 1, p. 19-32.

Missios Symeon, M. D. 2007. Hippocrates, Galen, and the uses of trepanation in the classical world. Neurosurg. Focus, 23 , p. $1-9$

Murphy, E. M. 2003. Trepanations and Perforated Crania from Iron Age South Siberia: An Exercise in Differential Diagnosis. In: Arnott, R., Finger, S., Smith, C. U. M. (eds.). Trepanation: History, discovery, theory. Lisse: Swets \& Zeitlinger Publishers, p. 209-221.

Nemeskeri, J., Kralovansky, A., Harsanyi, L. 1965. Trephined skulls from the tenth century. Acta Archaeologica Academiae Scientiarum Hungaricae, XVII, p. 343-367.

Nystrom, K. C. 2007. Trepanation in the Chachapoya region of Northern Peru. International Journal of Osteoarchaeology, 17, 1, p. 39-51.

Pitsios, Th., Zafiri, V. 2012. Cases of Trephination in Ancient Greek Skulls. International Journal of Caring Sciences, 5, 3, p. 239-245.

Rawlings, Ch. R., Rossitch, E. 1994. The History of Trephination in Africa with a Discussion of Its Current Status and Continuing Practice. Surgical Neurology, 41, p. 507-513.

Rubini, M. 2008. A Case of Cranial Trepanation in a Roman Necropolis (Cassino, Italy, $3^{\text {rd }}$ Century BC). International Journal of Osteoarchaeology, 18, p. 95-99.

Sankhyan, A. R., Weber, G. H. J. 2001. Evidence of Surgery in Ancient India: Trepanation at Burzahom (Kashmir) over 4000 Years Ago. International Journal of Osteoarchaeology, 11, p. 375-380.

The Cambridge... 1998. The Cambridge Encyclopedia of Human Paleopathology by Arthur C. Aufderheide \& Conrado Rodriguez-Martin. Cambridge: Cambridge University.
Tiago, T., Ana Maria, S., Collado, G. H., Oosterbeek, L. 2015-2016. Prehistoric trepanation in the Iberian Peninsula: a new case from the province of Badajoz (Extremadura, Spain). Antropologia Portuguesa, 32-33, p. 47-60.

Verano, J.W. 2003. Trepanation in Prehistoric Souht America: Geographic and Temporal Trends over 2,000 Years. In: Trepanation. History, Discovery, Theory. Lisse; Abingdon; Exton; Tokio: Swets \& Zeitlinger, p. 223-236.

Wikinson, R. G. 1975. Trephination by drilling in ancient Mexico. Bulletin of the New York Academy of Medicine, 51, 7, p. $838-850$.

Wilson Parry, T., Cantab, M. D. 1968. Trephination of the living human skull in prehistoric times. The British Medical Journal, 1923, p. 457-461.

Abramova, S. A. 1968. Novye pogrebeniya sarmatskogo vremeni iz Kabardino-Balkarii. Sovetskaya arkheologiya, 3, s. $114-130$.

Anuchin, D. N. 1895. Amulet iz chelovecheskogo cherepa i trepanacziya cherepov v drevnosti, v Rossii. Trudy XIV arkheologicheskogo sieezda, 1, 4, s. 18.

Balabanova, M. A., Pererva, E. V. Klepikov, V. M., Krivosheev, M. V., Demkin, V. A., Eltsov, M. V., Skripkin, A. S., Udaltsov, S. N., Iavorskaia, L. V., Diachenko, A. N. 2014. Kurganny mogilnik Peregruznoe I: rezultaty mezhdiscziplinarnykh issledovanij. Volgograd: FGBOU VPO RANXiGS.

Bejsenov, A. Z., Ismagulova, A. O., Kitov, E. P., Kitova, A. O. 2015. Naselenie Tsentralnogo Kazakhstana $v$ I tysyacheletii do n. e. Almaty: Institut arxeologii im. A. Hk. Margulana.

Bejsenov, A. Z., Kitov, E. P. 2014. Posmertnaya trepanatsiya cherepov v elitnykh zakhoroneniyakhx sakskoj epokhi Tsentralnogo Kazaxstana. Izvestiya AltGU, 4-2, 84, s. 31-41.

Boev, P., Ismagulov, O. 1962. Trepanirovanny cherep iz Kazakhskoj SSR. Sovetskaya etnografiya, 2, s. 131-132.

Buzhilova, A. P., Dobrovol'skaya, M. V., Mednikova, M. B. 2006. K probleme rekonstruktsii sotsialnykh vzaimootnoshenij naseleniya Barabinskoj stepi (analiz travm i povrezhdenij po antropologicheskim materialam serii Sopka 2). Arkheologiya, etnografiya $i$ antropologiya Evrazii, s. 148-156.

Vdovchenkov, E. V., Ilyashenko, S. M. 2016. Drevnie ogrableniya nekropolya Tanaisa ( $\mathrm{k}$ postanovke problemy). Trudy IIMK RAN, 46; Drevnie nekropoli i poseleniya: postpogrebal'nye ritualy, simvolicheskie zaxoroneniya i ogrableniya, s. 157-168.

Gavrilyuk, N. A., Timchenko, N. P. 2016. Fenomen ogrableniya stepnykh skifskikh pogrebenij v «makroekonomike» Severnogo Prichernomoria. Trudy IIMK RAN, 46; Drevnie nekropoli i poseleniya: postpogrebal'nye ritualy, simvolicheskie zaxoroneniya i ogrableniya, s. 129-133.

Gippokrat, 1936. Izbrannye knigi. Moskva: Gos. izd-vo biol. i med. lit.

Gokhman, I. I. 1980. Paleoantropologiya i doistoricheskaya meditsina. In: Alekseeva, T. I. (ed.). Antropologiya meditsine. Moskva: MGU, s. 5-16.

Grach, A. D. 1980. Dreunie kocheuniki v tsentre Azii. Moskva: Nauka.

Grigor'eva, M. A., Leonova, S. G. 2015. «Strah i trepet»: obryad obezvrezhivaniya v pogrebalnoj praktike iranoyazychnykh kochevnikov Severnogo Kavkaza. Kant, 3, 16, s. 16-21.

Gurenko, L. V. 1997. Otchet o provedenii arkheologicheskikh issledovanij $v$ Kumylzhenskom rajone Volgogradskoj oblasti (u stanitsy Glazunovskoj) v $1996 \mathrm{~g}$.

Zajczeva, O. V. 2005. Pogrebeniya s narushennoj anatomicheskoj tselostnostiju kostyaka: metodika issledovaniya $i$ vozmozhnosti interpretatsii: Dissertaciia k. i. n. Tomsk.

Kirichenko, D. A. 2007. O trepanatsii cherepa v drevnosti. Azarbaycan arxeologiyasэ vaetnoqrafiyasэ, 1, s. 63-67.

Kiselev, S. V. 1951. Drevnyaya istoriya Yuzhnoj Sibiri. Moskva: Nauka.

Krivosheev, M. V. 2017. Vostochnye traditsii i innovatsii v sarmatskikh pamyatnikakh vtoroj poloviny II-IV v. n. e. Vestnik Volgogradskogo gosudarstvennogo universiteta. Seriya 4: Istoriya. Regionovedenie. Mezhdunarodnye otnosheniya, 22, 4, s. 17-27.

Kyzlasov, L. R. 1960. Tashtykskaya epokha $v$ istorii Khakassko-Minusinskoj kotloviny (I v. do n. e. $-V$ v. n. e.). Moskva: MGU.

Lipskij, A. N. 1966. K voprosu ob ispolzovanii etnografii dlya interpretatsii arkheologicheskikh materialov. Sovetskaya etnografiya, 1, s. 105-118. 
Lisiczyn, Yu. P. 2004. Istoriya medicziny uchebnik. Moskva: Geotar.

Malashev, V. Yu. 2009. Pozdnesarmatskaya kultura: verkhnyaya khronologicheskaya granicza. Rossijskaya arkheologiya, 1, s. 47-51.

Mamontov, V. I., Obramenko, I. E., Pererva, E. V. 2018. Trepanatsiya cherepa iz zakhoroneniya srednesarmatskogo vremeni s territorii Volgogradskoj oblasti. Vestnik Moskovskogo universiteta. Seriya 23: Antropologiya, 1, s. 86-100.

Mednikova, M. B. 1997. K voprosu o rasprostranenii posmertnoj trepanatsii cherepov v Tsentralnoj Azii. Rossijskaya arkheologiya, 4, s. 130-188.

Mednikova, M. B. 2001. Trepanatsii u drevnikh narodov Evrazii. Moskva: Nauchnyj mir.

Mednikova, M. B. 2004. Trepanatsii v drevnem mire $i$ kult golovy. Moskva: Aleteja.

Naran, B., Tumen, D. 1997. Travmaticheskie povrezhdeniya na cherepakh Chandmanskogo mogilnika. Rossijskaya arkheologiya, 4, s. 122-130.

Nechitajlo, A. L. 2004. Eneoliticheskie pogrebeniva s perforirovannymi cherepami v stepyakh Evrazii. In: Problemy arkheologi Nizhnego Povolzhija. I Mezhdunarodnaya Nizhnevolzhskaya arkhe ologicheskaya konferentsiya. Tezisy dokladov. Volgograd, s. 61-63.

Pererva, E. V. 2012. Sluchaj trepanatsii u sarmatov (po antropologicheskim materialam iz mogilnika Peregruznoe I) Vestnik Moskovskogo universiteta. Seriya XXIII, 2, s. 123-133.

Pigolkin, Yu. I., Barinov, E. Kh., Bogomolov, D. V., Bogomolova, I. N. 2002. Sudebnaya meditsina. Moskva: Geotar-med.

Rokhlin, D. G. 1960. Bolezni drevnikh lyudej (kosti lyudej razlichnykh epokh normalnye i patologicheskie izmeneniya). Moskva; Leningrad: Nauka.

Rudenko, S. I. 1949. Kultura Altaya vremeni sooruzheniya pazyrykskikh kurganov. Kratkie soobshchenija IIMK, XXVI, s. 97-109.

Rudenko, S. I. 1953. Kultura naseleniya Gornogo Altaya v skifskoe vremya. Moskva; Leningrad: AN SSSR.

Rudenko, S. I. 1960. Kultura naseleniya Tsentralnogo Altaya $v$ skifskoe vremya. Moskva; Leningrad: AN SSSR.

Sidorov, V. V. 1997. Akt sudebno-mediczinskogo issledovaniya N 8. In: Gurenko, L. V. Otchet o provedenii arkheologicheskikh issledovanij v Kumylzhenskom rajone Volgogradskoj oblasti (u staniczy Glazunovskoj) v 1996 g. Arkhiv N 8.

Skripkin, A. S. 1992. Aziatskaya Sarmatiya. Problemy khronologii, periodizatsii $i$ etnopoliticheskoj istorii. Nauchny doklad, predstavlenny $v$ kachestve dissertatsii na soiskanie uchenoj stepeni doktora istoricheskikh nauk. Moskva.

Skripkin, A. S. (ed.). 2009. Arkheologicheskaya encziklopediya Volgogradskoj oblasti. 2009. Volgograd: VolGU.

Smirnov, Yu. A. 1997. Labirint: mifologiya prednamerennogo pogrebeniya. Moskva: Vostochnaya literatura.

Smolyaninov, V. M. 1959. Sudebnaya meditsina: uchebnik dlya studentov med. in-tov. Moskva: Medgiz.

Tokarev, S. A. 1990. Rannie formy religii. Moskva: Politizdat.

Fialkov, L. 2010. Istoriya meditsiny. Khajfa: JKDesign.

Flyorov, V. S. 2000. Alany Tsentralnogo Predkavkaziya V-VIII vekov: obryad obezvrezhivaniya pogrebionnykh. Trudy Klin-Yarskoj ekspeditsii, I. Moskva: Polimedia.

Khokhlov, A. A. 2012. Ritualnye travmy na cherepakh u nositelej khvalynskoj eneoliticheskoj kultury Povolzhiya. Et nograficheskoe obozrenie, 2 , s. 118-125.

Khudaverdyan, A. Yu. 2015. Trepanirovannye cherepa iz pogrebenij epokhi pozdnej bronzy i rannego zheleznogo veka $\mathrm{s}$ territorii Armenii. Vestnik arkheologii, antropologii $i$ etnografii, 2 (29), s. 115-127.

Chikisheva, T. A.,Zubova,A. V., Krivoshapkin, A. L., Kurbatov, V. P. Volkov, P. V. Titov, A. T. 2014. Kompleksnoe issledovanie trepanatsij u rannikh kochevnikov Gornogo Altaya. Arkheologiya, etnografiya $i$ antropologiya Evrazii, 1, 57, s. 130-141.

Yaczenko, S. A. Kostyum drevnej Evrazii (iranoyazychnye narody). Moskva: Vostochnaya literatura.

Yaczenko, S. A. 2007. O zhenshhinakh-«zhriczax» u rannikh kochevnikov (na primere znatnykh sarmatok I v. do n. e. - II vv. n. e.). Mirovozzrenie narodov Yuzhnoj Sibiri $i$ Tsentralnoj Azii v istoricheskoj retrospective, 1, s. 1-8.

Yaczenko, S. A. 2016. Kharakter drevnikh ograblenij kurganov dvukh grupp sarmatskoj elity' I - II vv. n. e. Trudy IIMK $R A N, 46$ : Drevnie nekropoli i poseleniya: postpogrebalnye ritualy, simvolicheskie zakhoroneniya i ogrableniya, s. 147-156.

\section{E. V. Pererva}

\section{TREPANATION IN THE SARMATIANS OF THE LOWER VOLGA REGION (Revisiting its Causes and Origins)}

Skull trepanation of the is one of the most frequently performed operations on human skull by modern and ancient surgeons. Trepanation is often associated in the scientific literature with such widespread manipulations in ancient peoples' bodies as deliberate head or extremities deformation, scalping, artificial scarification, decapitation and truncation of limbs, etc. Nowadays, it is known that trepanation is therapeutic or ritual manipulation done in vivo or posthumous. Also skull trepanation is performed by various techniques. The definition of all these criteria allows anthropologists to evaluate the nature of the development of medical knowledge of ancient societies, to determine the degree of technical sophistication of ancient doctors, to understand the traditions and customs of peoples who lived on earth in the distant past.

The paper is an attempt to summarize and consider cases of craniotomy on craniological materials dating back to the Sarmatian era. Evaluation of the described fixed manipulations from the point of view of the technique of carrying out the operations and the reasons for their conduct is also given in the study. An attempt was made to find the sources of the spread of the tradition of skull trepanation in the nomadic peoples of the Early Iron Age who inhabited the Lower Volga region.

Keywords: Trepanation, sarmatians, ancient societies, skull, Early Iron Age, the Lower Volga region.

\section{Є. В. Перерва}

\section{ТРЕПАНАЦІЯ У САРМАТІВ НИЖ- НЬОГО ПОВОЛЖЯ (до роздумів про пошук причин і витоків традиції)}

Трепанація черепа - одна з найбільш частих операцій, що проводяться на черепній коробці людини сучасними давніми хірургами. У науковій літературі антропологами приділяеться велика увага трепанації, поряд 3 такими поширеними у давніх народів маніпуляціями з тілом людини, як навмисна деформація голови або кінцівок, скальпування, штучне шрамирування, декапітация і усічення кінцівок тощо. Сьогодні відомо, що трепанації бувають терапевтичними або ритуальними, прижиттевими і посмертними. Також трепанації голови поділяються за технікою їх проведення. Визначення всіх цих критеріїв дозволяє антропологам оцінити характер розвитку медичних знань стародавніх суспільств, визначити ступінь технічного озброєння давніх медиків, зрозуміти традиції і звичаї народів, що жили на землі в далекому минулому

Пропонована робота є спробою підсумувати і розглянути випадки трепанації черепа на краниологічних матеріалах сарматської доби. Дається оцінка описаних зафіксованих маніпулящій з точки зору техніки здійснення операцій причини їх проведення. Зроблено спробу пошуку витоків поширення традиції трепанації черепа у кочових народів епохи раннього залізного віку, які жили на території Нижнього Поволжя.

Ключові слова. Трепанація, сармати, давні суспільства, черепи, ранній залізний вік, Нижне Поволжя.

Одержано 3.04.2020

ПЕРЕРВА Свгеній Володимирович, кандидат історичних наук, доцент, Волгоградський державний університет, пр-т Університетський, 100, Волгоград, 400062, Росія.

PERERVA Evgeny V., Candidate of Historical Sciences, Associate Professor, Volgograd State University, Prospect Universitetsky, 100, 400062, Volgograd, Russia.

ORCID: 0000-0001-8285-4461, e-mail: evgeniy.pererva@volsu.ru. 